\title{
Histomorphological Description of the Digestive System of Pebbly Fish, Alestes baremoze (Joannis, 1835)
}

\author{
Nasser Kasozi, ${ }^{1}$ Gerald Iwe Degu, ${ }^{1}$ Julius Mukalazi, ${ }^{1}$ Charles Drago Kato, ${ }^{2}$ Majid Kisekka, \\ Akisoferi Owori Wadunde, ${ }^{3}$ Godfrey Kityo, ${ }^{3}$ and Victoria Tibenda Namulawa ${ }^{3}$ \\ ${ }^{1}$ Abi Zonal Agricultural Research \& Development Institute, National Agricultural Research Organisation, \\ P.O. Box 219, Arua, Uganda \\ ${ }^{2}$ College of Veterinary Medicine, Animal Resources \& Biosecurity, Makerere University, P.O. Box 7062, Kampala, Uganda \\ ${ }^{3}$ Aquaculture Research \& Development Center, National Agricultural Research Organisation, P.O. Box 530, Kampala, Uganda
}

Correspondence should be addressed to Victoria Tibenda Namulawa; tibendavyky@yahoo.com

Received 15 February 2017; Revised 1 May 2017; Accepted 14 May 2017; Published 17 July 2017

Academic Editor: Thomas E. Adrian

Copyright (C) 2017 Nasser Kasozi et al. This is an open access article distributed under the Creative Commons Attribution License, which permits unrestricted use, distribution, and reproduction in any medium, provided the original work is properly cited.

\begin{abstract}
Histomorphological studies of the digestive system of Alestes baremoze captured from Lake Albert, Uganda, were done using standard procedures. These revealed that A. baremoze has a fleshy-lipped terminal small mouth, large molar, short oesophagus, a three-lobed liver, pouch-like stomach, a nine-fingered caeca, and a long tubular intestine. A stratified squamous epithelium with numerous mucus-secreting cells lined the lips with no taste buds. Stratified squamous epithelia lined the oesophagus in the anterior portion which turned into a columnar epithelium towards the stomach. The lamina propria had numerous tubular glands throughout the entire oesophageal length. The stomach consisted of three distinct regions (cardiac, fundic, and pyloric) with distinguished lamina propria glands. The intestinal mucosa was thrown into villi of varying heights, with the tallest in the anterior part, lined with a simple columnar epithelium with numerous lymphocytes-like infiltrations. Numerous goblet cells appeared in the intestinal lamina epithelialis; these increased uniformly towards the anal opening. The liver was divided into lobules, with a central vein. Hepatocytes were visibly arranged closely, forming irregular cords, and the scattered tubular acinar glands formed the exocrine pancreas (hepatopancreas). Stomach content analysis indicated that the fish eats plankton, mollusks, crustaceans, and insects as the main proportion of its diet.
\end{abstract}

\section{Introduction}

Alestes baremoze (Joannis, 1835) or Pebbly fish is native to freshwater systems in Africa, thriving well in both lacustrine and riverine conditions. It belongs to order Characiformes, family Alestidae, and genus Alestes [1]. In East Africa, the fish appears in Lake Albert, Lake Turkana, and the Albert and Murchison Niles. In Northeast Africa, the species is present in the Ghazal and Jebel systems, White and Blue Niles in Sudan, and the River Nile, as far as Lake Nasser. In West Africa, it appears in Chad, Niger/Benue, Volta, Comoé, and Bandama [1]. In Uganda, Alestes baremoze is a delicacy and a high value fish species particularly in the West-Nile region, where it is also popularly known as "Angara" [2,3]. Studies indicate that the fish has been extensively harvested, putting it under threat [1]. Similarly, recent research indicates tremendous species decline $[2,4]$. The fact that Alestes baremoze is increasingly getting scare, yet greatly demanded on the market, makes it one of the species worth considering for commercial aquaculture. Despite the vast studies conducted to understand the feeding ecology of this fish in Lake Albert $[5,6]$, no information is available on the anatomy of its digestive system.

Insights into the anatomy of the digestive system of an aquaculture candidate fish are of importance in guiding development of appropriate feeding strategies of the fish once cultured $[7,8]$. The structure of fish gut is a complex system [9], responsible for food ingestion, digestion, and assimilation [10], and the way this is done depends on the anatomical design of the digestive system [11]. For this reason, 


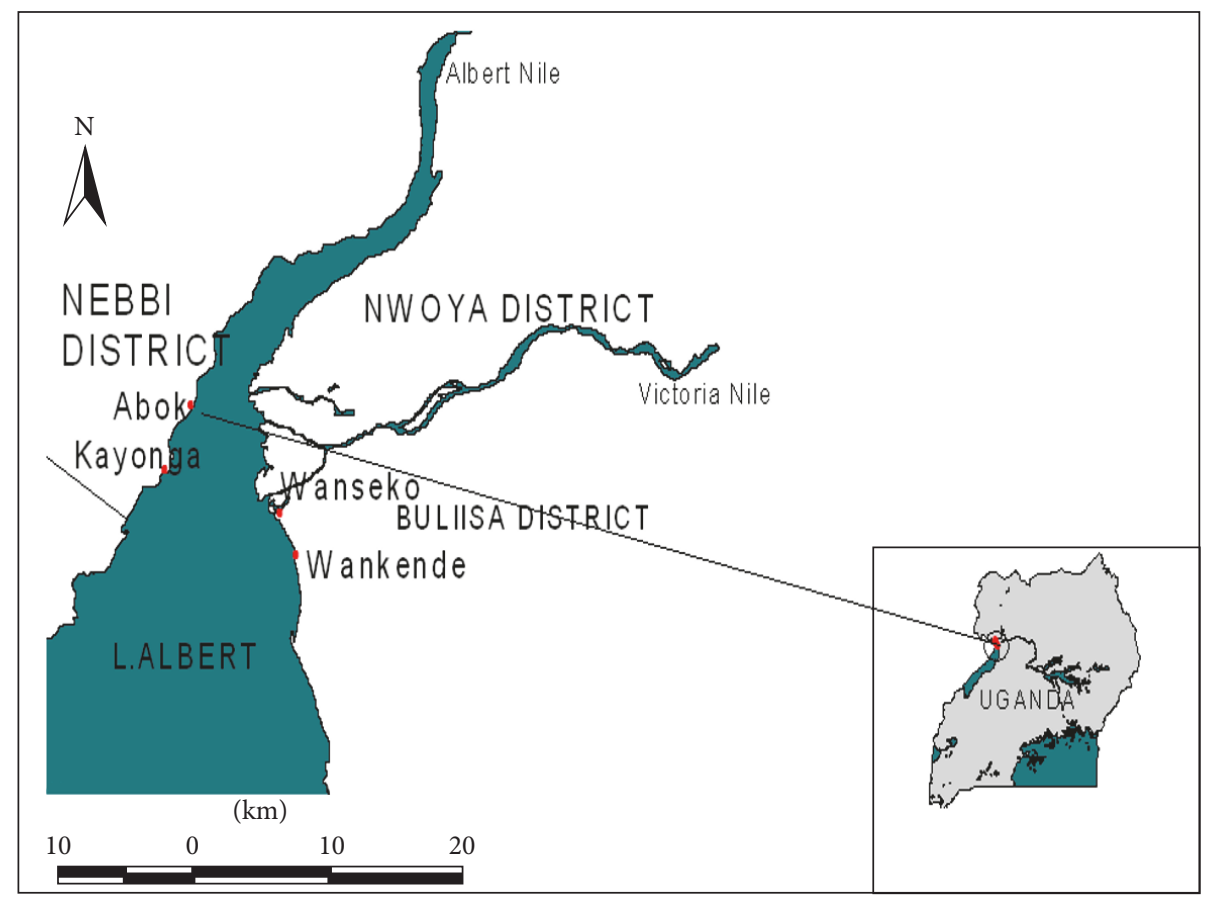

- Landing sites Lakes and rivers

FIGURE 1: Map showing the study site.

several studies have been done to describe the structure of the digestive system in different fish species [12-15]. Similarly, several research teams have analysed the relative gut length (RGL) in fishes and their feeding regimes [16-18]. However, no such investigation has been done in A. baremoze, and this limits the understanding of the functioning of the digestive system in this fish and its diet, yet such information is important to guide the development of feeding strategies in farmed fish. The aim of this study therefore was to describe the histomorphology of the digestive system of $A$. baremoze and its RGL and stomach content so as to gain insights into the functioning of this system; such information will guide the development of appropriate feeding strategies for this fish once cultured.

\section{Materials and Methods}

2.1. Sample Collection. A total of 20 samples of males and females of adult $A$. baremoze were caught using gill nets of 4 inches from Lake Albert and landed at Abok fish landing site $\left(02^{\circ} 14.46^{\prime} \mathrm{N} 31^{\circ} 19.15^{\prime} \mathrm{E}\right)$ located in Panyimur subcounty on Lake Albert (Figure 1). The fish samples had a mean fork length of $40.7( \pm 1.47) \mathrm{cm}$ and mean body weight of $1052( \pm 277) \mathrm{g}$. The fresh samples were dissected to expose the entire digestive system. The topography and gross anatomy of the digestive system were then described following successful dissection of the individual organs. At each dissection step, photographs of both the fixed and fresh samples were taken using a digital camera (Kodak EasyShare C763-7.1 megapixels).
2.2. Histological Description. Tissue sections comprising four of each of the different digestive system sections (oral cavity, oesophagus, stomach, caeca, intestine, and liver) were instantly fixed in Bouin's solution. Standard histological procedures [16] were used in tissue processing. The prepared tissue sections were stained using haematoxylin and eosin (H\&E) and Masson's trichrome staining protocol [17]. The stained sections were then visualised under a Carl Zeiss (German) light microscope mounted with a 10-megapixel digital camera (Canon PowerShot A640, China). Microphotographs were captured and analysed using the ZoomBrowser EX photographic software (version 2.0).

2.3. Relative Gut Length. Gut lengths $(\mathrm{cm})$ and total body lengths $(\mathrm{cm})$ were obtained from 90 samples collected over a period of nine months (pooled samples of males and females). The values of relative gut indices of adult $A$. baremoze were studied [18] using the following formula: relative gut length $=$ gut length $[\mathrm{cm}] /$ standard body length $[\mathrm{cm}]$.

2.4. Stomach Content Analysis. The contents of the stomach were collected separately and preserved in 70\% ethanol before transportation to Makerere University for analysis. The stomach contents were identified under a light microscope $(10-100 x)$ and analysed using point methods [18, 19]. Food items were awarded points based on the volumes they were judged to have occupied. Stomach fullness was assessed on a 0 -100-point scale with $0,25,50,75$, and 100 representing empty stomach, quarter full, half full, three-quarter full, and full stomachs, respectively. 


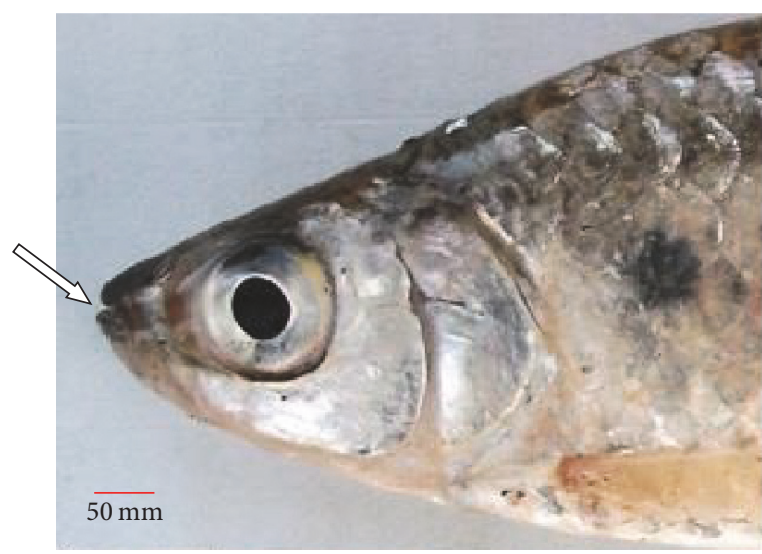

(a)

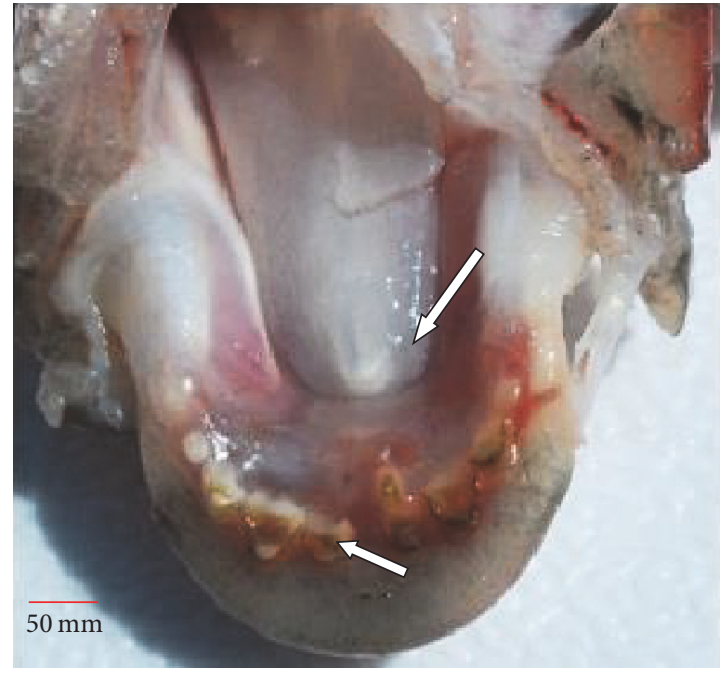

(c)

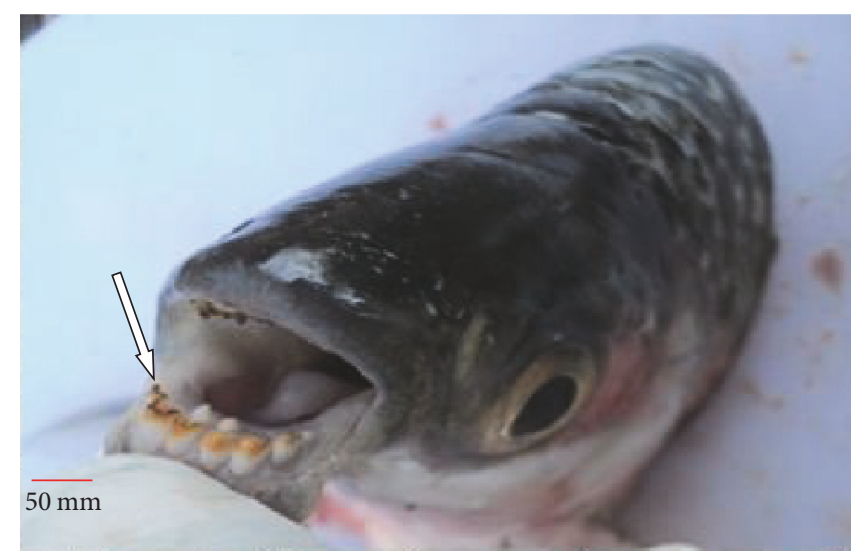

(b)

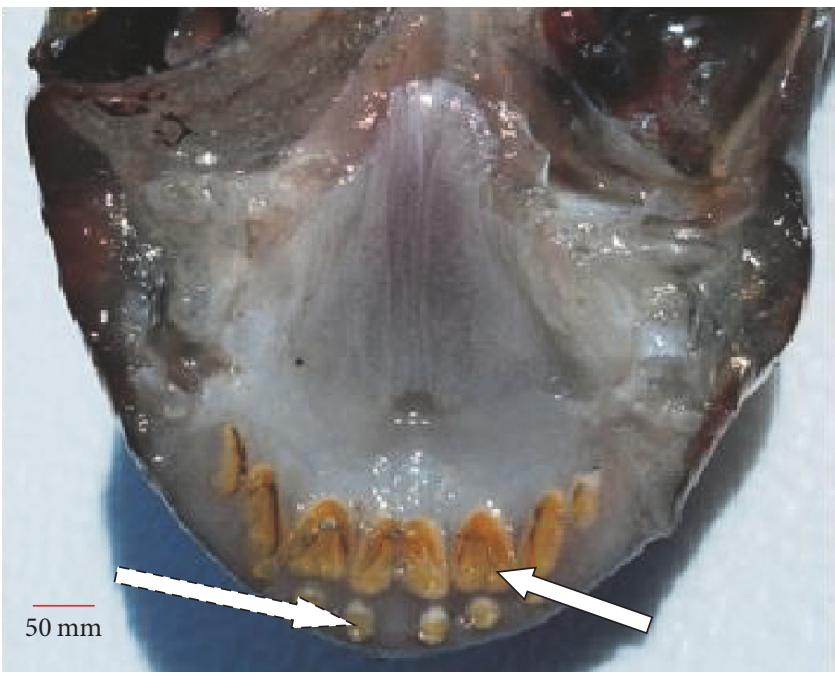

(d)

Figure 2: Gross morphology: (a) terminal mouth ( $)$, (b) dentition ( $(\mathrm{d})$ molar $(\ll)$ and conical teeth $(\diamond)$ on the premaxilla in the upper jaw.

\section{Results}

3.1. Gross Morphological Description. Alestes baremoze has a fusiform shape typical of fast moving fish with relatively large scales. It has a bright silver colour which darkens on the dorsal surface with relatively large eyes, typical of characins. Gross morphological investigations revealed that the oral cavity opens through a fleshy-lipped terminal small mouth (Figure 2(a)). Inside the cavity was a soft textured tongue inclined to the lower jaw and large molars (Figure 2(b)) arranged in one raw (Figure 2(c)). The premaxilla had two teeth rows, one composed of conical teeth and the other composed of molars (Figure 2(d)). No valve was observed between the pharynx and the oesophagus. In the viscera (Figure 3(a)), the digestive system lay parallel to the gonads and the gas bladder. The short muscular oesophagus lay alongside the liver, posterior to the oral cavity, and joined the pharynx to the stomach. The muscular pouch-like stomach lay adjacent to the three-lobed liver and the anterior section of the intestine. The stomach was divided into the cardiac, fundic, and pyloric regions. The liver had two short lobes on the left, with one attached to the gall bladder and one longer lobe positioned to the right. A pyloric sphincter occurred between the pylorus section of the stomach and the duodenal section of the intestine, where nine-finger-like pyloric caeca were attached (Figure 3(b)). Posterior to the short duodenum was a looped intestine that lay alongside the gonads and gas bladder. The intestine had folds similar to those observed in the caeca (Figure 4). The intestinal diameter gently increased towards its hind section, ending into a narrow annual opening and the mean relative intestinal length was $1.2 \pm 0.085 \mathrm{~cm}$ (Table 1 ).

3.2. Stomach Contents Analysis. Sixteen different prey categories were collected from the stomachs of 90 samples and recorded. Adult $A$. baremoze were found with stomachs predominantly containing insects $(80.37 \%)$, with molluscs, 
TABLE 1: Relative gut length of A. baremoze collected from Lake Albert, Uganda.

\begin{tabular}{lcccc}
\hline Month & $\begin{array}{c}\text { Average body length } \\
(\mathrm{cm})\end{array}$ & $\begin{array}{c}\text { Average gut length } \\
(\mathrm{cm})\end{array}$ & $\begin{array}{c}\text { Sample number } \\
\text { Average relative gut length }\end{array}$ & 1.3 \\
\hline April & 42.5 & 53.8 & 10 & 20 \\
May & 42.5 & 51.1 & 10 & 1.2 \\
June & 42 & 49.7 & 5 & 1.2 \\
July & 37.7 & 51.9 & 7 & 1.4 \\
August & 39.5 & 53.3 & 11 & 1.3 \\
September & 41.8 & 46.3 & 8 & 1.1 \\
October & 38.8 & 47.1 & 10 & 1.2 \\
November & 42.5 & 49.8 & 9 & 1.2 \\
December & 40.3 & 50 & & 1.2 \\
\hline
\end{tabular}

Average RGL for all samples (April to December) $=1.2 \pm 0.085$.

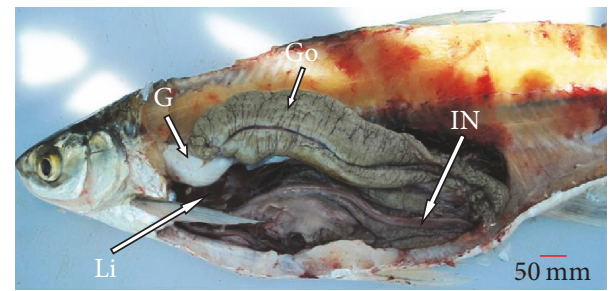

(a)

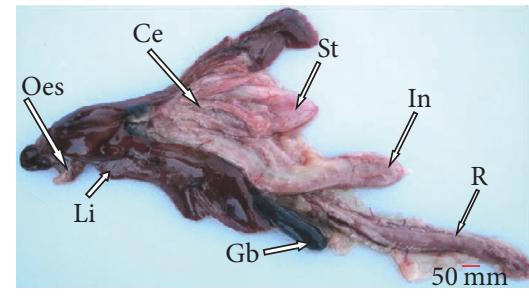

(b)

FIGURE 3: (a) Topography of the GIT and associated organs: gonad (Go), gas bladder (G), liver (Li), and intestine (IN). (b) Organs of the GIT: oesophagus (Oes), liver (Li), rectum (R), stomach (St), intestine (In), gall bladder (Gb), and caeca (Ce).

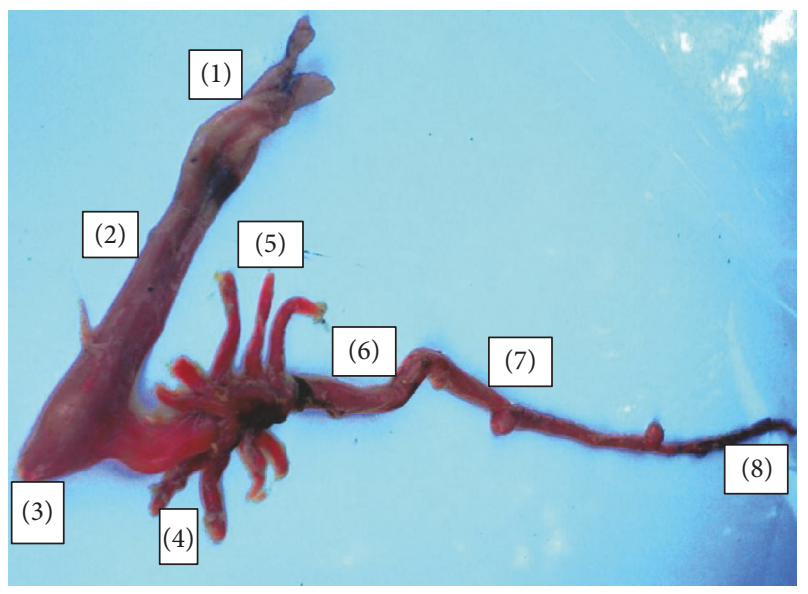

FIgURE 4: Structure of the digestive tract of A. baremoze. (1) Esophagus, (2) cardiac stomach, (3) fundic stomach, (4) pyloric stomach, (5) pyloric caeca, (6) anterior intestine, (7) mid intestine, and (8) posterior intestine/rectum.

crustaceans, and food items constituting lesser proportions (Table 2).

\subsection{Histology}

3.3.1. Lip. The lip surface was lined with a stratified squamous epithelium and numerous mucous secreting cells. Underlying this was cartilaginous and skeletal muscle. No taste buds were observed in the lip (Figure 5(a)).
3.3.2. Palate. The roof of the oral cavity was formed by a palate lined by a stratified squamous epithelium with numerous epithelial folds (Figure 5(b)). Below this was the lamina muscularis which formed a demarcation between the epithelial layer and the propria submucosa. The propria submucosa of the palate was made of dense irregular connective tissue. Beneath this underlay cartilage and bone (Figure 5(c)).

3.3.3. Tongue. The tongue was lined by a stratified squamous epithelium on the dorsum, with numerous lymphocytes-celllike infiltrations (Figure 5(d)). The propria submucosa of the tongue was made of loose connective tissue with numerous adipose tissues. A thin layer of skeletal muscle, the lamina muscularis, separated the lamina epithelialis from the propria submucosa. The bulk of the tongue was shaped by underlying cartilage.

3.3.4. Oesophagus. The oesophagus was lined by a stratified squamous epithelium in the anterior portion which turned into a columnar epithelium towards the cardiac stomach (Figure 6). The lamina propria had numerous tubular glands throughout the entire length of the oesophagus. The mucosa was thrown into several folds supported by loose connective tissue from the submucosa. Numerous blood vessels were observed in the submucosa. The tunica muscularis had an inner circular muscle layer and an outer longitudinal skeletal muscle layer. Tunica muscularis turned from skeletal to smooth muscle towards the stomach. 
TABLE 2: Point assessment percentages of various categories of food items in the stomachs of Alestes baremoze collected from Lake Albert, Uganda, during the year 2016.

\begin{tabular}{lcc}
\hline Category & Food items & Point assessment percentages \\
\hline \multirow{2}{*}{ Insecta } & Remains of winged insect & 90 \\
& Dragonflies & 80 \\
& Ephemeroptera (nymph) & 77 \\
\hline Mollusca & Adult grasshoppers & 74.5 \\
\hline & Gastropoda & 47.5 \\
Crustacea & Ostracoda & 27.3 \\
& Daphnia & 27 \\
& Shrimps & 17 \\
& Cyclops & 11 \\
& Moina & 22.9 \\
Other food items & Detritus & 2.6 \\
& Phytoplankton (Microcystis and Chlorella) & 2.58 \\
& Eggs & 2.5 \\
\end{tabular}

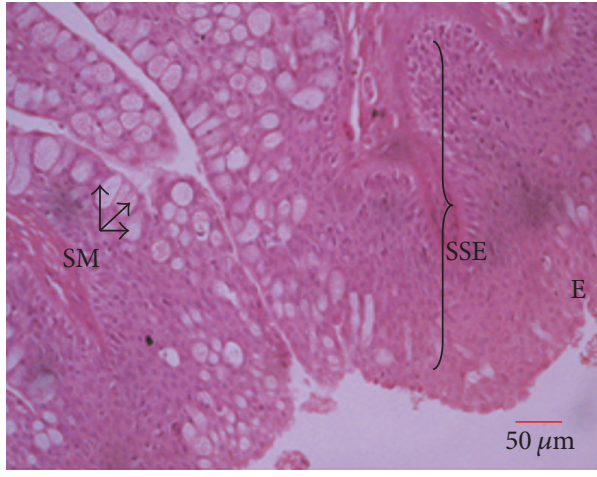

(a)

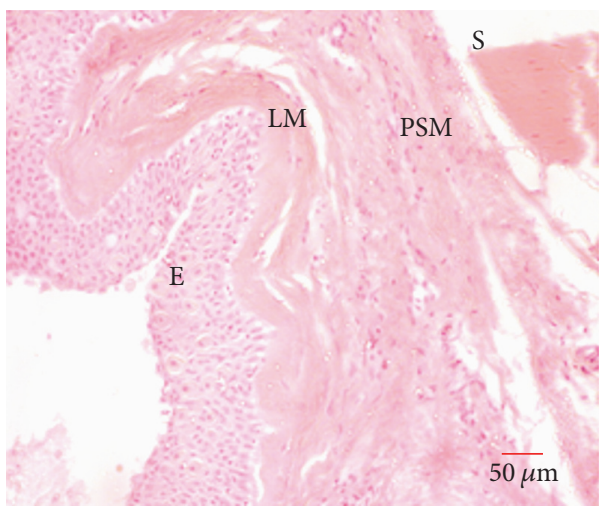

(c)

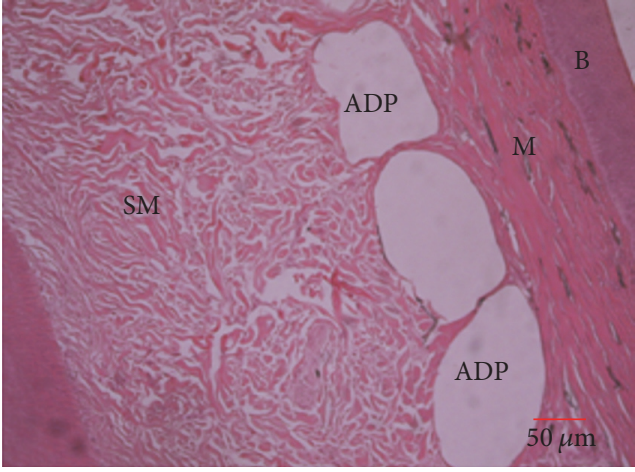

(b)

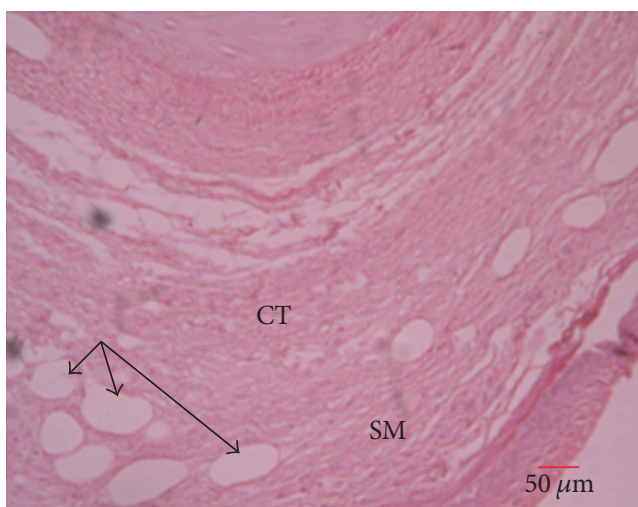

(d)

FIGURE 5: Oral cavity. (a) Lips: skeletal muscles (SM) and stratified squamous epithelium (SSE) with goblet cells (arrows). (b) Palate-roof of the oral cavity: epithelium (E), submucosa (SM) with irregular connective tissue, adipose tissue (ADP), skeletal muscle (M), and underlying bone (B). (c) Floor of the oral cavity: epithelium (E), laminar muscularis (LM), propria submucosa (PSM), and skeletal muscle (SM). (d) Tongue: adipose tissue (arrows), skeletal muscle (SM), connective tissue (CT), and underlying cartilage (C).

3.3.5. Stomach. The stomach consisted of three distinct regions that were distinguished on the basis of glands in the lamina propria, the cardiac, fundic, and pyloric regions. In all the parts, the stomach was lined by a simple columnar epithelium. Laminar muscularis was not observed in the stomach.
The lamina propria had numerous straight tubular glands (Figure $7(\mathrm{a})$ ) that appeared shorter in the pyloric region as compared to the fundic and cardiac regions. The submucosa was made of loose connective tissue with numerous blood vessels. Tunica muscularis consisted of inner circular and 


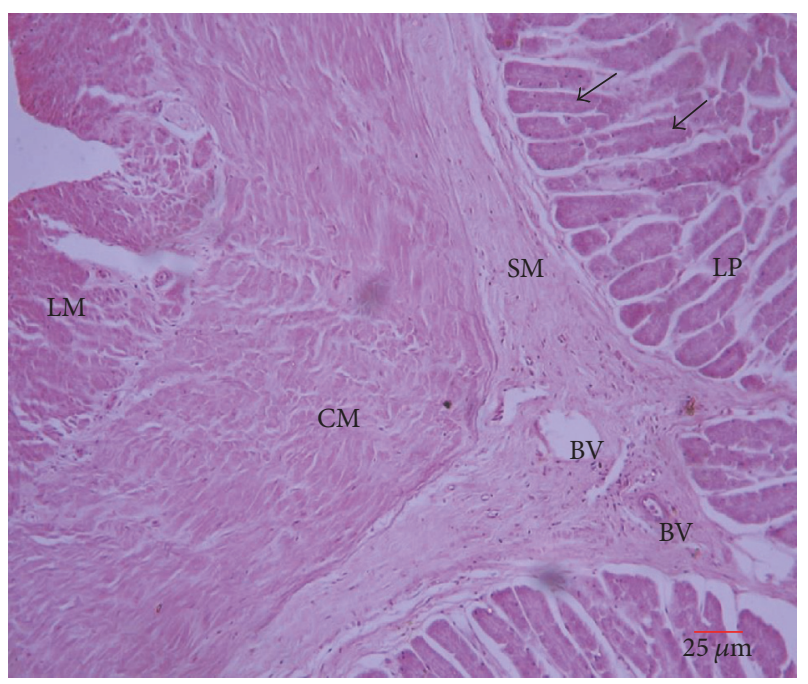

FIgURE 6: Transverse section of esophagus: lamina propria (LP), submucosa (SM), blood vessel (BV), inner circular muscle (CM), and outer longitudinal muscle (LM). Arrows: tubular glands.

outer longitudinal smooth muscle layers (Figure 7(b)). The longitudinal muscle layer was slightly thicker in the fundic region of the stomach. The serosa was a single layer of squamous cells beneath the muscularis.

3.3.6. Liver. The liver was divided into lobules by connective tissue sheets with a central vein in the middle (Figure $8(a)$ ). The hepatocytes were visible throughout the liver parenchyma arranged close to each other forming irregular cords. Throughout the liver lobules were scattered tubular acinar glands of the exocrine pancreas, forming the hepatopancreas and secretory vesicles (Figure 8(b)).

3.3.7. Intestine. The mucosal layer of the intestine was thrown into folds (villi) of varying sizes (Figure 9(a)). Villi were tallest in the anterior part of the intestine. The mucosa was lined with a simple columnar epithelium with numerous lymphocytes cell-like infiltrations. Numerous goblet cells that increased in number towards the anal opening were seen in the lamina epithelialis. The submucosa was thin with its connective tissue extending the entire length of the villi. Tunica muscularis was made up of inner circular and outer longitudinal layer of smooth muscle (Figure 9(b)). The histological organization of the caeca was identical to that of the anterior and posterior intestine but with less villi and goblet cells.

\section{Discussion}

Histomorphological studies in fish have increasingly become important, given the growing interest in aquaculture [20], since the structure of the digestive system in fish indicates its feeding behaviour and provides insights into feeding strategies for cultured fish [21, 22]. Gross morphological investigations in this study revealed that the oral cavity in A. baremoze

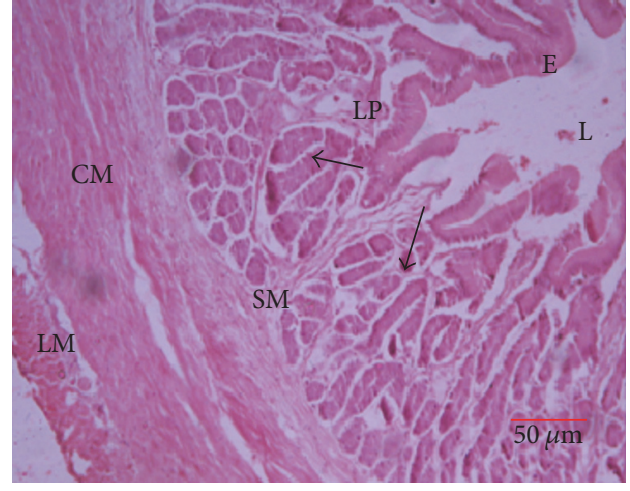

(a)

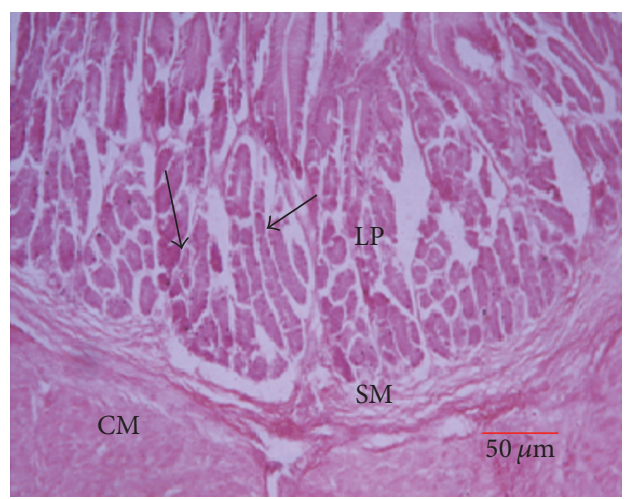

(b)

Figure 7: Transverse section through the stomach. (a) Cardiac stomach and (b) fundic stomach: lumen (L), epithelium (E), submucosa (SM), lamina propria (LP), circular muscle layer (CM), and longitudinal muscle (LM).

is composed of a small fleshy-lipped terminal mouth, with both conical and molariform dentitions. Similar mouth structures have been observed in Cheilinus lunulatus [23], with molariform and conical teeth common in Clarias gariepinus [24], Herichthys minckleyi [25], Aphanius persicus [26], and Chrysobrycon eliasi [27]. Terminal mouths in fish have been related to chasing and capture of small food items [28], while the presence of teeth on the jaws enables the predator to hold and grasp prey items [29]. Similarly, conical dentitions have been associated with soft bodied predators [30], while molariform dentations have been associated with mollusc and crustacean feeders [23]. The presence of these two dentition types in A. baremoze suggests that this fish feeds on a variety of food items but mainly of animal origin. Histological investigations further revealed the presence of several goblet cells in the epithelium lining the oral cavity, several skeletal muscles, adipose tissue, and an underlying cartilage in the cavity. Similar observations have been reported in Oreochromis niloticus and Clarias gariepinus [31], where presence of mucus secreting glands was suggested to imply secretion of copious amounts of mucus needed to lubricate the oral cavity to ease swallowing. Meanwhile the presence of muscle networks and adipose tissue suggests ease of mouth movement during mastication and a cushion of fat cells to act as a shock absorber during food acquisition and swallowing. 


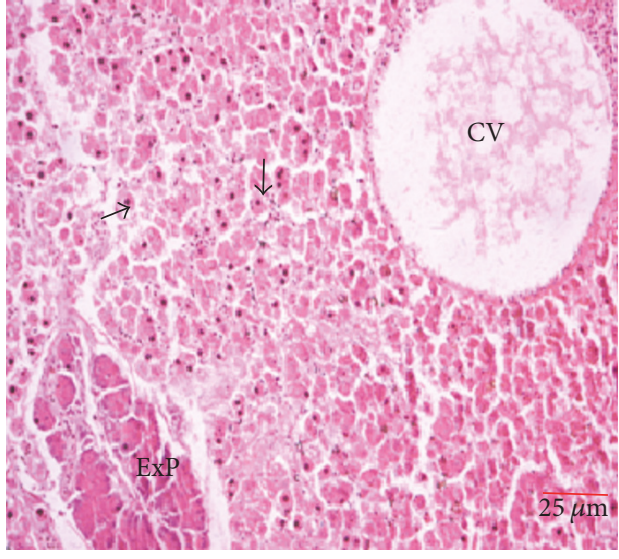

(a)

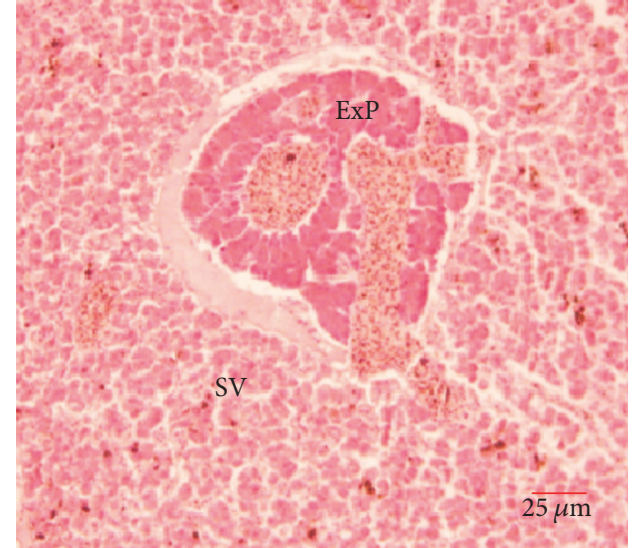

(b)

FIGURE 8: Liver: (a) CV, central vein, and (b) ExP, exocrine pancreas with secretory vesicles (SV), with hepatocytes arranged in irregular cords.

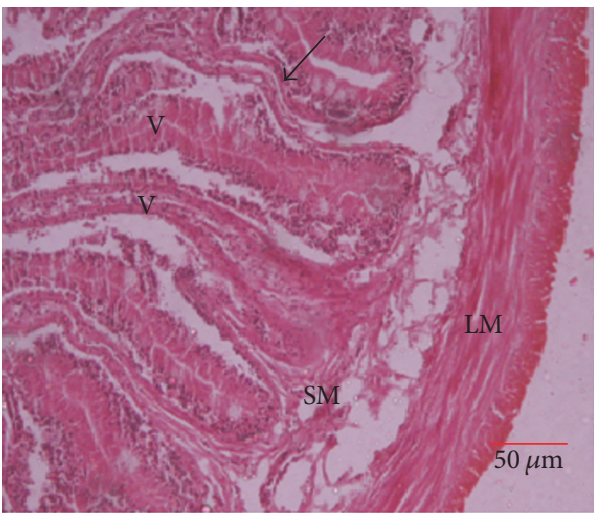

(a)

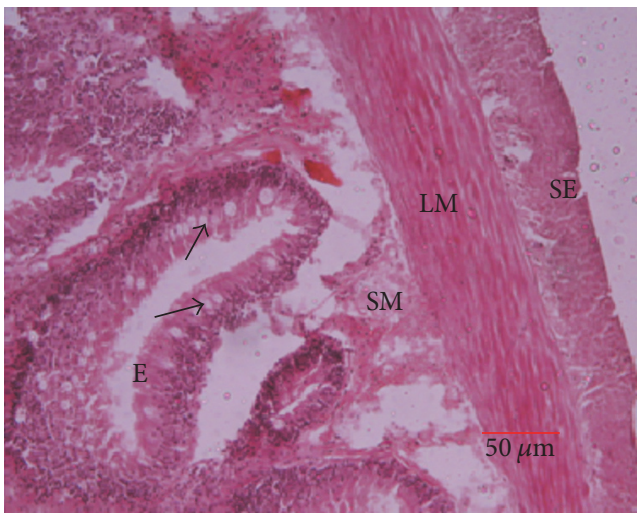

(b)

FIgURE 9: Intestine: E, epithelium, SM, submucosa, V, villi, SE, serosa, and LM, longitudinal muscle; arrows are goblet cells.

The oesophagus in A. baremoze in this study is short and has numerous tubular glands located in the lamina propria. The mucosa is also greatly folded, while the tunica muscularis is well developed with inner circular muscles and outer longitudinal skeletal muscles. Similar reports have been given in other fishes such as Clarias gariepinus and Ctenopharyngodon idella [32]. All these studies conclude that the numerous mucosal folds provide for increased surface area for chemical activity. Similarly, several tubular glands were also observed in the lamina propria of the oesophagus in $A$. baremoze in this study. This therefore suggests that chemical digestion in A. baremoze begins in the oesophagus.

Study results reveal the presence of a pouch-like stomach in A. baremoze, whose lamina propria had numerous straight tubular glands, as has been reported in Esox lucius [33, 34] and Lates niloticus [35]. In these fishes, the presence of a pouch-shaped stomach has been related to large feed quantity intake, which is slowly digested by chemical substances released from the tubular glands. This could be the mechanism of digestion also occurring in A. baremoze.
Morphological observations indicated that the liver in A. baremoze is three-lobed and lies adjacent to the oesophagus, stomach, and the anterior section of the intestine. Histologically, the liver parenchyma contained tubular acinar glands which constituted the exocrine pancreas forming the hepatopancreas. This arrangement is similar to what was observed in several fish and freshwater bivalves [17, 36]. However, the hepatopancreas is not observed in higher vertebrates [37].

Similarly, observations made in this study reveal that A. baremoze has a nine-fingered caeca and a long tubular intestine lying alongside the gonads. Multifingered caeca have been reported in several other fishes and have been proposed to be important in chemical digestion [38], absorption [39], osmoregulation [40], food storage, lipid absorption, and optimising $\mathrm{pH}$ for digestion [41]. Histologically, the organisation of the intestine did not significantly differ from that of the caeca. The arrangement of this structure is in agreement with findings by [42] and is suitable for absorbing digested food [43]. 
The RGL of A. baremoze in this study was $1.2 \pm 0.085$ (Table 1). The relationship between RGL and trophic levels in fishes has been documented [15]. This relationship is believed to reflect the digestive processing time required for different food material. Herbivorous fish species, for instance, tend to have higher RGL compared to omnivorous and carnivorous fishes due to the fibrous plant material they ingest, which requires longer digestion time. Although the RGL varies with fish species and growth stages, [16] categorises fish as either carnivorous ( $\mathrm{RGL}=0.6-0.8)$, omnivorous $(\mathrm{RGL}=0.8-1.0)$, or herbivorous $(\mathrm{RGL}=2.5-16.4)$. This suggests that $A$. baremoze is an omnivorous fish, a situation confirmed by observations made from its stomach contents (Table 2), which were seen to cut across plant and animal material. According to [1], A. baremoze has a flexible diet, shifting from zooplankton to zoobenthos, detritus, and macrophytes as plankton densities decline. Findings reported by [6] on food web structure in Lake Albert suggest that ontogenetic shifts occurred in the diet of A. baremoze and this was partly driven by structural changes in feeding apparatus and morphology that opened up new and unexploited feeding opportunities. Similarly, size specific shifts in food or habitat type have been documented in many species [44, 45]. Previous studies related to feeding ecology on one of the closest relatives, Alestes nurse in the Alestidae family, by [44] indicated that $A$. nurse was observed to change its food diet from phytoplankton and small zooplankton during their premetamorphosis stages to larger zooplankton. The observed dietary shifts observed in A. baremoze suggest that this fish can survive on a variety of food items and this makes it a good aquaculture candidate with ability to survive on formulated diets given that these are developed from a variety of raw materials both of plan and animal origin.

\section{Conclusion}

Histomorphological observations and stomach content analysis performed in this study suggest that $A$. baremoze has morphological adaptations for omnivory. The molariform dentation observed in the adult fish also helps them to feed on hard bodied organisms. Further investigations to assess the ability of $A$. baremoze to digest formulated diets will be useful.

\section{Conflicts of Interest}

The authors declare that there are no conflicts of interest regarding the publication of this paper.

\section{Acknowledgments}

This work was supported by the grant from the Competitive Grant Scheme of the National Agricultural Research Organisation (NARO) under the Agricultural Technology and Agribusiness Advisory Services (ATAAS) project and was implemented by Abi Zonal Agricultural Research and Development Institute (Abi ZARDI), CGS Project ID/no: CGS/4/32/14.

\section{References}

[1] E. Akinyi, A. Awaïss, A. Azeroual, A. Getahun, P. Lalèyè, and T. Twongo, "Alestes baremoze," in IUCN 2012. IUCN Red List of Threatened Species. Version 2012.2, 2010.

[2] D. Mbabazi, M. A. Taabu, L. I. Muhoozi et al., "The past, present and projected scenarios in the lake Albert and Albert nile fisheries: implications for sustainable management," Uganda Journal of Agricultural Sciences, vol. 13, no. 2, pp. 47-64, 2012.

[3] N. Kasozi, G. I. Degu, K. Atibuni, M. Kisekka, A. OworiWadunde, and S. Mugerwa, "Classification of ovarian stages of Alestes baremoze (Joannis, 1835): a step towards understanding its reproductive biology," Frontiers in Science, vol. 3, no. 4, pp. 107-113, 2013.

[4] "NaFIRRI (National Fisheries Resources Research Institute)," Capture fisheries in Uganda; The Nile perch fishery; Traditional and Emerging Fisheries; Overfishing and the use of illegal gears on Lake Albert. Jinja, Uganda, Policy Brief No. 1, 2012.

[5] M. J. Holden, "The feeding habits of Alestes baremose and Hydrocynus forskali (Pisces) in Lake Albert, East Africa," Journal of Zoology, vol. 161, no. 1, pp. 137-144, 1970.

[6] L. M. Campbell, S. B. Wandera, R. J. Thacker, D. G. Dixon, and R. E. Hecky, "Trophic niche segregation in the Nilotic ichthyofauna of Lake Albert (Uganda, Africa)," Environmental Biology of Fishes, vol. 74, no. 3-4, pp. 247-260, 2005.

[7] K. L. Riley, C. R. Weirich, and D. Cerino, "Development and growth of hatchery-reared larval Florida pompano (Trachinotus carolinus)," Fishery Bulletin, vol. 107, no. 3, pp. 318-328, 2009.

[8] I. Rønnestad, M. Yúfera, B. Ueberschär, L. Ribeiro, Ø. Sæle, and C. Boglione, "Feeding behaviour and digestive physiology in larval fish: Current knowledge, and gaps and bottlenecks in research," Reviews in Aquaculture, vol. 5, no. 1, pp. S59-S98, 2013.

[9] J. Abowei and A. T. Ekubo, "Some principles and requirements in fish nutrition," British Journal of Pharmacology and Toxicology, vol. 2, no. 4, pp. 163-178, 2011.

[10] J. Sweetman, A. Dimitroglou, S. Davies, and S. Torrecillas, "Nutrient uptake, gut morphology: a key to efficient nutrition," International Aqua Feed, vol. 8, pp. 26-30, 2008.

[11] R. K. Buddington, A. Krogdahl, and A. M. Bakke-Mckellep, "The intestines of carnivorous fish: structure and functions and the relations with diet," Acta Physiologica Scandinavica, Supplementum, no. 638, pp. 67-80, 1997.

[12] R. Hofer, "Morphological adaptations of the digestive tract of tropical cyprinids and cichlids to diet," Journal of Fish Biology, vol. 33, no. 3, pp. 399-408, 1988.

[13] C. Ribeiro and E. Fanta, "Microscopic morphology and histochemistry of the digestive system of a tropical freshwater fish Trichomycterus brasiliensis (Lütken) (Siluroidei, Trichomycteridae)," Revista Brasileira de Zoologia, vol. 17, no. 4, pp. 953-971, 2000.

[14] W. H. Karasov, C. Martínez Del Rio, and E. Caviedes-Vidal, "Ecological physiology of diet and digestive systems," Annual Review of Physiology, vol. 73, pp. 69-93, 2011.

[15] B. Canan, W. S. do Nascimento, N. B. da Silva, and S. Chellappa, "Morphohistology of the digestive tract of the damsel fish Stegastes fuscus (Osteichthyes: Pomacentridae)," The Scientific World Journal, vol. 2012, Article ID 787316, 9 pages, 2012.

[16] D. P. German and M. H. Horn, "Gut length and mass in herbivorous and carnivorous prickleback fishes (Teleostei: Stichaeidae): Ontogenetic, dietary, and phylogenetic effects," Marine Biology, vol. 148, no. 5, pp. 1123-1134, 2006. 
[17] P. Karachle and K. Stergiou, "Gut length for several marine fish: relationships with body length and trophic implications," Marine Biodiversity Records, vol. 3, article e106, 2010.

[18] A. M. Davis, P. J. Unmack, B. J. Pusey, R. G. Pearson, and D. L. Morgan, "Ontogenetic development of intestinal length and relationships to diet in an Australasian fish family (Terapontidae)," BMC Evolutionary Biology, vol. 13, no. 1, article no. 53, 2013.

[19] T. Downie, “Theory and Practice of Histological Techniques Edited by J.D. Bancroft \& A. Stevens, Churchill Livingstone, Edinburgh, 740 pages, $£ 55.00$," Histopathology, vol. 17, no. 4, pp. 386-386, 1990.

[20] N. E. El-Bakary and H. L El-Gammal, "Comparative histology, histochemistry and ultrastuctural studies on the proximal intestines of flathead grey mullet (Mugil cephalus) and sea bream (Sparus aurata)," World Applied Science Journal, vol. 8, pp. 477-485, 2010.

[21] H. B. N. Hynes, "The Food of Fresh-Water Sticklebacks (Gasterosteus aculeatus and Pygosteus pungitius), with a Review of Methods Used in Studies of the Food of Fishes," The Journal of Animal Ecology, vol. 19, no. 1, p. 36, 1950.

[22] E. J. Hyslop, "Stomach contents analysis-a review of methods and their application," Journal of Fish Biology, vol. 17, no. 4, pp. 411-429, 1980.

[23] E. Ikpegbul, D. N. Ezeasor, U. C. Nlebedum, and O. Nnadozie, "Observations on the oesogaster of the domesticated african catfish (Clarias gariepinus, Burchell, 1822)," Bulgarian Journal of Veterinary Medicine, vol. 16, no. 2, pp. 88-95, 2013.

[24] P. C. Wainwright and B. A. Richard, "Predicting patterns of prey use from morphology of fishes," Environmental Biology of Fishes, vol. 44, no. 1-3, pp. 97-113, 1995.

[25] S. A. Lakshmi, "Interrelationship between the alimentary tract, food and feeding habits of plueronectiform fishes of southeast coast of India," Journal of Experimental Sciences, vol. 1, no. 6, pp. $1-7,2010$.

[26] M. M. Hassan and A. Khalaf, "Morphological adaptations of digestive tract according to food and feeding habits of the broomtail wrasse, Cheilinus lunulatus," Egyptian Journal of Aquatic Biology and Fisheries, vol. 17, no. 1, pp. 123-141, 2013.

[27] A. M. Gamal, E. H. Elsheikh, and E. S. Nasr, "Morphological adaptation of the buccal cavity in relation to feeding habits of the omnivorous fish Clarias gariepinus: a scanning electron microscopic study," Journal of Basic \& Applied Zoology, vol. 65, no. 3, pp. 191-198, 2012.

[28] C. D. Hulsey, J. Marks, D. A. Hendrickson, C. A. Williamson, A. E. Cohen, and M. J. Stephens, "Feeding specialization in Herichthys minckleyi: A trophically polymorphic fish," Journal of Fish Biology, vol. 68, no. 5, pp. 1399-1410, 2006.

[29] M. Monsefi, Z. Gholami, and H. Esmaeili, "Histological and morphological studies of digestive tube and liver of the persian tooth-carp, Aphanius persicus (Actinopterygii cyprinodontidae)," Journal of Biology, vol. 69, no. 1, pp. 157-164, 2010.

[30] J. A. Vanegas-Ríos, M. D. L. M. Azpelicueta, and H. Ortega, "Chrysobrycon eliasi, new species of stevardiine fish (Characiformes: Characidae) from the río madre de dios and upper río manuripe basins, Peru," Neotropical Ichthyology, vol. 9, no. 4, pp. 731-740, 2011.

[31] R. Fugi, A. A. Agostinho, and N. S. Hahn, "Trophic morphology of five benthic-feeding fish species of a tropical floodplain," Revista Brasileira de Biologia, vol. 61, no. 1, pp. 27-33, 2001.

[32] S. Chattopadhyay, S. Nandi, and S. K. Saikia, "Mouth morphometry and architecture of freshwater catfish Mystus vittatus Bloch
(1974) (Siluriformes, Bagridae) in relation to its feeding habit," Journal of Scientific Research, vol. 6, no. 1, pp. 169-174, 2014.

[33] E. H. Elsheikh, "Scanning electron microscopic studies of gill arches and rakers in relation to feeding habits of some fresh water fishes," Journal of Basic \& Applied Zoology, vol. 66, pp. 121-130, 2013.

[34] A. S. Awaad, U. K. Moawad, and M. G. Tawfiek, "Comparative histomorphological and histochemical studies on the oesophagus of nile Tilapia Oreochromis niloticus and african catfish Clarias gariepinus," Journal of Histology, vol. 2014, Article ID 987041, 10 pages, 2014.

[35] E. A. Abd El Hafez, D. M. Mokhtar, A. S. Abou-Elhamd, and S. H. Ahmed Hassan, "Comparative histomorphological studies on oesophagus of catfish and grass carp," Journal of Histology, vol. 2013, Article ID 858674, p. 10, 2013.

[36] D. Bucke, "The anatomy and histology of the alimentary tract of the carnivorous fish the pike Esox lucius L.," Journal of Fish Biology, vol. 3, no. 4, pp. 421-431, 1971.

[37] L. J. Chapman, W. C. Mackay, and C. W. Wilkinson, "Feeding flexibility in northern pike (Esox lucius): fish versus invertebrate prey," Canadian Journal of Fisheries and Aquatic Sciences, vol. 46, no. 4, pp. 666-669, 1989.

[38] V. T. Namulawa, C. D. Kato, E. Nyatia, P. Britz, and J. Rutaisire, "Histomorphological description of the digestive system of nile perch (L. niloticus)," International Journal of Morphology, vol. 29, no. 3, pp. 723-732, 2011.

[39] A. V. Andhale, P. A. Bhosale, and S. P Zambare, "Histopathological study of nickel induced alterations in the fresh water bivalve, Lammellidens marginalis," Journal of Experimental Sciences, vol. 2, no. 4, pp. 1-3, 2011.

[40] D. E. Malarkey, K. Johnson, L. Ryan, G. Boorman, and R. R. Maronpot, "New insights into functional aspects of liver morphology," Toxicologic Pathology, vol. 33, no. 1, pp. 27-34, 2005.

[41] S. Khantaphant and S. Benjakul, "Comparative study on the proteases from fish pyloric caeca and the use for production of gelatin hydrolysate with antioxidative activity," Comparative Biochemistry and Physiology - B Biochemistry and Molecular Biology, vol. 151, no. 4, pp. 410-419, 2008.

[42] S. H. Sugiura and R. P. Ferraris, "Contributions of different NaPi cotransporter isoforms to dietary regulation of $\mathrm{P}$ transport in the pyloric caeca and intestine of rainbow trout," Journal of Experimental Biology, vol. 207, no. 12, pp. 2055-2064, 2004.

[43] P. A. Veillette, R. J. White, J. L. Specker, and G. Young, "Osmoregulatory physiology of pyloric ceca: Regulated and adaptive changes in chinook salmon," Journal of Experimental Zoology Part A: Comparative Experimental Biology, vol. 303, no. 7, pp. 608-613, 2005.

[44] F. S. Rios, A. L. Kalinin, M. N. Fernandes, and F. T. Rantin, "Changes in gut gross morphology of traíra, Hoplias malabaricus (Teleostei, Erythrinidae) during long-term starvation and after refeeding," Brazilian Journal of Biology, vol. 64, no. 3B, pp. 683-689, 2004.

[45] T. Ba-Omar, V. Reginald, and D. Tobias, "Some aspects of the anatomy and histology of digestive tracts in two sympatric species of freshwater fishes," Science and Technology, vol. 8, pp. 97-106, 2003. 

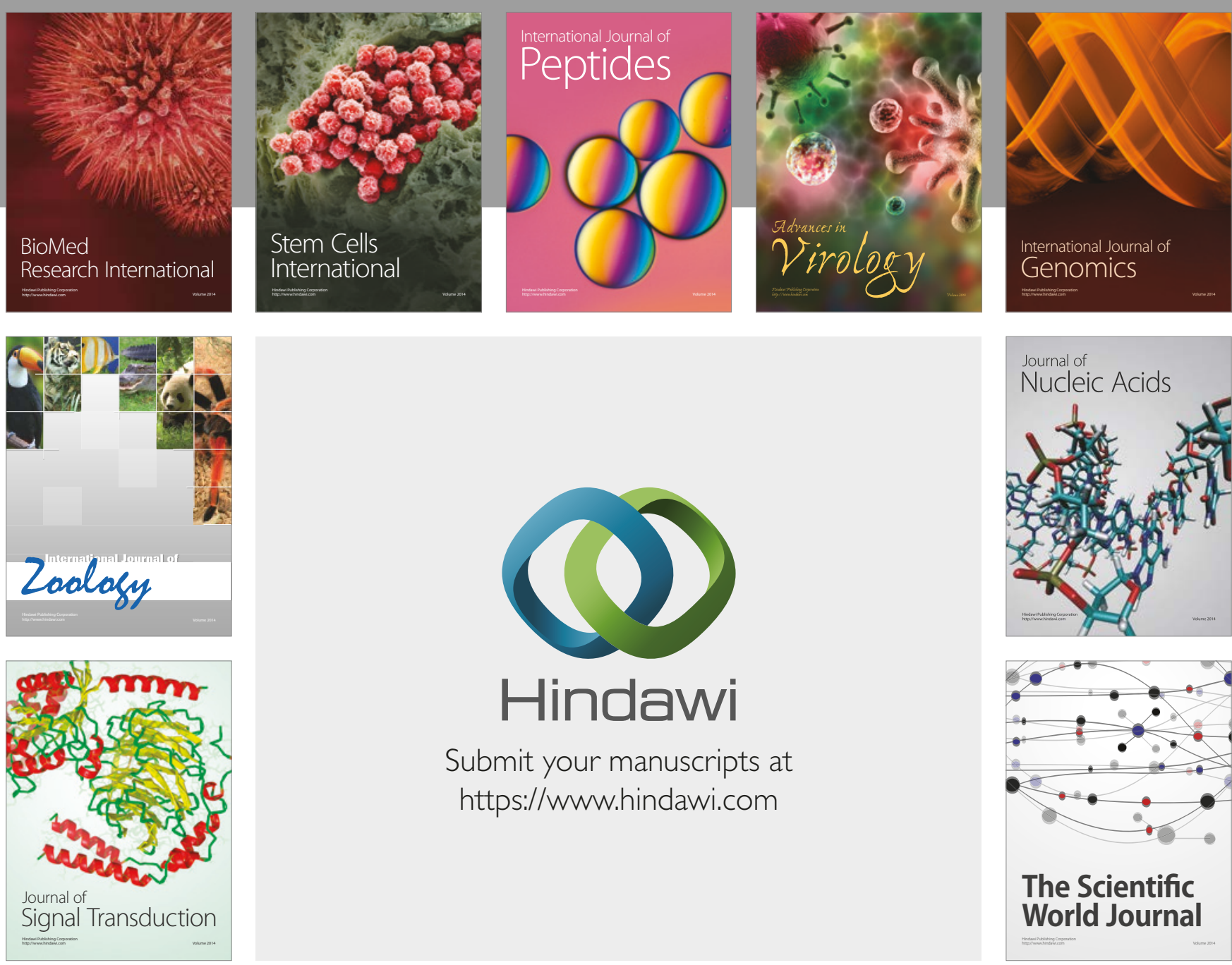

Submit your manuscripts at

https://www.hindawi.com
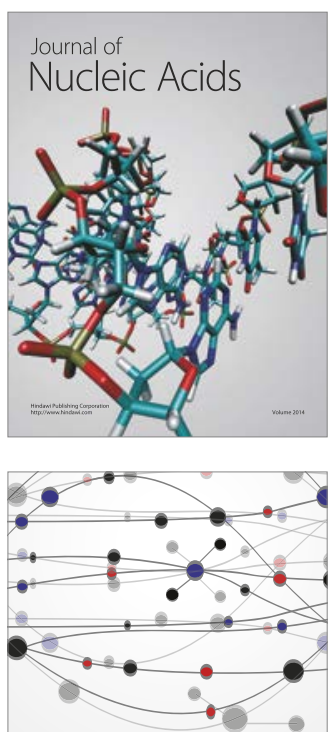

The Scientific World Journal

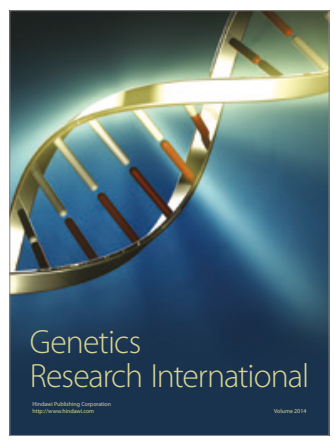

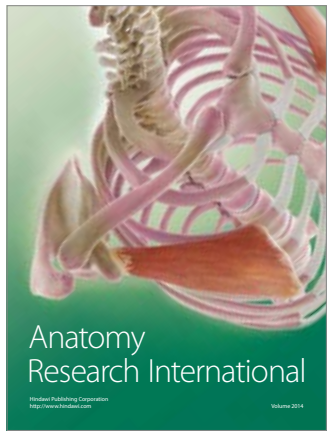

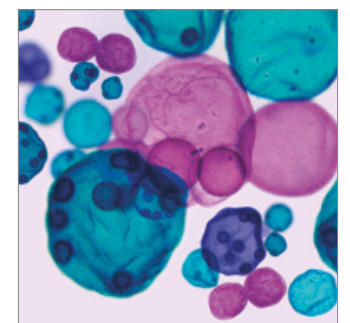

International Journal of Microbiology
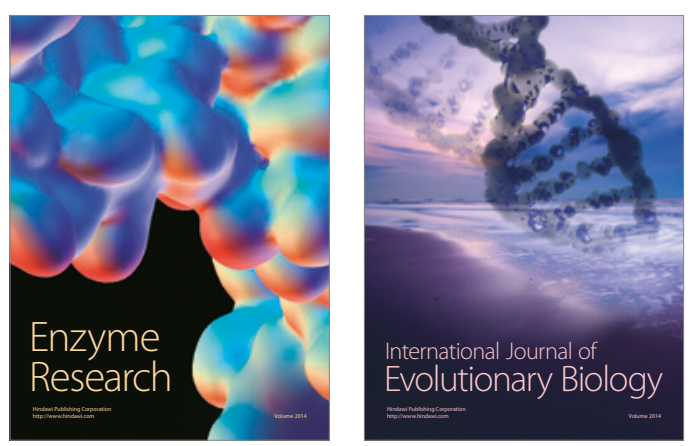
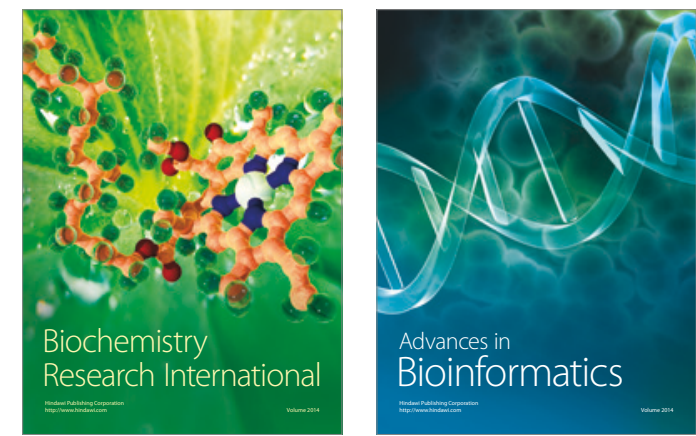

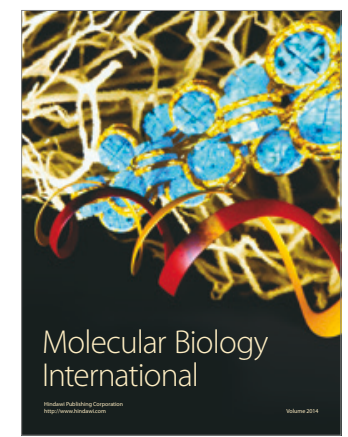

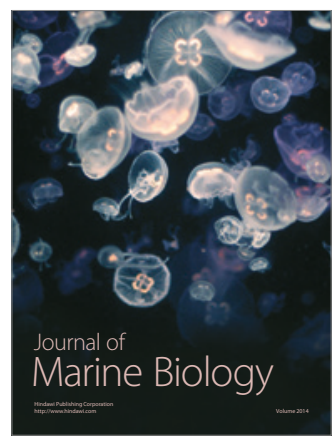

